\title{
PENGARUH MANAJEMEN LABA DAN KINERJA KEUANGAN TERHADAP PERINGKAT OBLIGASI (STUDI KASUS PADA LEMBAGA KEUANGAN PERBANKAN DI BURSA EFEK INDONESIA)
}

\author{
Yeni Ratnawati ${ }^{1}$ \\ Putri Awalina ${ }^{2}$ \\ ${ }^{1}$ Prodi Akuntansi Fakultas Ekonomi Universitas Islam Kadiri \\ ${ }^{2}$ Prodi Akuntansi Fakultas Ekonomi Universitas Islam Kadiri
}

\begin{abstract}
Abstrak
Perbankan adalah badan usaha yang menghimpun dana dari masyarakat dalam bentuk simpanan dan menyalurkannya kepada masyarakat dalam bentuk kredit dan atau bentuk-bentuk lainnya dalam rangka meningkatkan taraf hidup rakyat banyak. Setiap satu tahun sekali perbankan membuat laporan keuangan perusahaan, untuk mengetahui pencapaian kinerjanya selama periode berjalan. Perbankan mengeluarkan obligasi untuk memperoleh tambahan modal dari investor. Penilaian obligasi dipengaruhi oleh manajemen laba dan kinerja keuangan.

Dalam penilaian manajemen laba menggunakan total akrual dari Healy yang tercantum dalam Sari dan Bandi (2010). Peniliaian kinerja lembaga keuangan perbankan dinilai dari rasio likuiditas diproksikan dengan quick ratio, rasio solvabilitas diproksikan dengan primary ratio dan rasio rentabilitas diproksikan dengan return on equity. Data yang digunakan dalam penelitian ini adalah data kuantitatif dan data kualitatif. Data kuantitatif meliputi laporan laba rugi dan neraca tahun 2015-2017. Data kualitatif meliputi diskripsi dari lembaga keuangan perbankan.

Subjek penelitian ini adalah perusahaan yang go public di Bursa Efek Indonesia dan terdaftar di PT. PEFINDO tahin 2015-2017. Pemilihan sampel dilakukan dengan metode purposive sampling, sehingga diperoleh 6 perusahaan yang memenuhi kriteria dengan 3 tahun pengamatan. Data yang digunakan berupa data sekunder yang berasal dari laporan keuangan dan database peringkat obligasi
\end{abstract}


PT. Pefindo, sedangkan analisis data menggunakan analisis regresi linier berganda.

Hasil penelitian menunjukkan bahwa rasio likuiditas dan rasio solvabilitas berpengaruh terhadap peringkat obligasi. Sedangkan manajemen laba dan rasio rentabilitas tidak berpengaruh terhadap peringkat obligasi. Simpulan penelitian ini adalah dari 4 variabel yang digunakan dalam penelitian ini hanya variabel rasio likuiditas dan rasio solvabilitas yang dapat digunakan untuk memprediksi peringkat obligasi suatu lembaga keuangan perbankan. Saran yang dapat diberikan kepada peneliti selanjutnya adalah menambah sampel dan periode yang diteliti.

Kata Kunci : manajemen laba, likuiditas, solvabilitas, rentabilitas

\begin{abstract}
Banking is a business entity that collects funds from the public in the form of deposits and distributes them to the public in the form of loans and / or other forms in order to improve the lives of many people. Every year, banks make financial statements of companies, to find out their performance achievements during the period. Banks issue bonds to obtain additional capital from investors. Bond valuation is influenced by earnings management and financial performance.

In the assessment of earnings management using total accruals from Healy listed in Sari and Bandi (2010). The assessment of the performance of banking financial institutions is assessed from the liquidity ratio proxied by the quick ratio, the solvency ratio is proxied by the primary ratio and the profitability ratio is proxied by return on equity. The data used in this study are quantitative data and qualitative data. Quantitative data includes income statements and balance sheets for 2015-2017. Qualitative data includes descriptions of banking financial institutions.

The subject of this study is a company that goes public on the Indonesia Stock Exchange and is registered at PT. Yearly 2015-2017 PEFINDO. Sample selection was done by purposive sampling method, so that 6 companies were obtained that met the criteria with 3 years of observation. The data used in the form of secondary data derived from financial statements and the bond rating database of PT. Pefindo, while data analysis uses multiple linear regression analysis.

The results showed that liquidity ratios and solvency ratios had an effect on bond ratings. While earnings management and profitability ratios have no effect on bond ratings. The conclusion of this study is that of the 4 variables used in this study only liquidity ratio and solvability ratios can be used to predict the bond ratings of a banking financial institution. The advice that can be given to the next researcher is to add the sample and the period under study.
\end{abstract}

Keywords: earnings management, liquidity, solvency, profitability 


\section{PENDAHULUAN}

Investasi merupakan salah satu variabel yang sangat penting dalam menggerakkan perekonomian suatu negara. Investasi merupakan suatu alat untuk mempercepat pertumbuhan di suatu negara yang sedang berkembang. Investasi dibedakan menjadi dua macam yaitu investasi nyata dan investasi keuangan. Investasi nyata yaitu investasi yang dilakukan dengan memberikan barang bernilai ekonomi yang diperlukan dalam proses produksi, contohnya adalah tanah, mesin, atau pabrik. Investasi keuangan yaitu investasi yang diwujudkan dalam bentuk membeli dokumen atau surat-surat berharga dari perusahaan dengan harapan memperoleh keuntungan jika usahanya semakin besar, contohnya adalah saham dan obligasi.

Menurut Bursa Efek Indonesia obligasi dapat dijelaskan sebagai surat utang jangka menengah panjang yang dapat dipindahtangankan, yang berisi janji dari pihak yang menerbitkan untuk membayar imbalan berupa bunga pada periode tertentu dan melunasi pokok utang pada waktu yang telah ditentukan kepada pihak pembeli obligasi tersebut. Obligasi dapat diterbitkan oleh korporasi maupun Negara. Obligasi dapat memberikan penghasilan tetap yaitu berupa kupon bunga dan pokok utang pada waktu jatuh tempo yang ditentukan.

Obligasi akan mendapatkan pemeringkatan secara berkala yang dikeluarkan oleh lembaga pemeringkat obligasi. Peringkat obligasi dikeluarkan oleh lembaga pemeringkat yaitu salah satunya adalah PT PEFINDO. Menurut Hickman (1958) dalam Yasa (2010) peringkat obligasi digunakan secara ekstensif dalam komunikasi investasi sebagai informasi pengukuran risiko obligasi. Jadi peringkat obligasi dapat digunakan untuk mengetahui signal tentang probabilitas kegagalan pembayaran utang perusahaan dan kinerja dari perusahaan tersebut.

Penerbitan obligasi, perusahaan akan dengan jelas menyatakan jumlah dana yang dibutuhkan yang dikenal dengan istilah jumlah emisi obligasi. Penentuan besar kecilnya jumlah penerbitan obligasi berdasarkan aliran arus kas perusahaan, kebutuhan, serta kinerja bisnis perusahaan. Jika kinerja bisnis perusahaan terlihat baik maka jumlah emisi obligasi juga dapat ditingkatkan, sedangkan kinerja perusahaan yang baik dapat dihasilkan salah satunya dengan praktek manajemen laba.

Manajemen laba merupakan suatu penyimpangan dalam penyusunan laporan keuangan, yaitu mempengaruhi tingkat laba yang ditampilkan dalam laporan keuangan. Manajemen laba ini dilakukan untuk memberikan suatu informasi kepada agen pemeringkat mengenai kinerja keuangan perusahaan yang positif, sehingga bisa memberikan peringkatyang terbaik. Dengan peringkat yang baik ini tentu dapat meningkatkan kepercayaan dan memaksimalkan dana yang masuk kedalam perusahaan. Manajemen laba juga mempengaruhi penerbitan obligasi suatu perusahaan.

Pemeringkatan obligasi salah satu variabel yang mempengaruhi adalah kinerja keuangan dari suatu perusahaan. Salah satu cara untuk mengetahui kinerja keuangan suatu perusahaan adalah dengan menghitung tingkat rasio keuangan perusahaan. Rasio keuangan dapat memberikan gambaran yang jelas tentang kinerja manajemen suatu usaha dalam periode tertentu dan dapat digunakan untuk pertimbangan dalam pengambilan keputusan.

Penilaian rasio keuangan terhadap lembaga keuangan perbankan berbeda dengan perusahaan manufaktur karena dalam aktivitasnya lembaga keuangan 
hanya memberikan jasa tanpa menjual barang. Perbankan merupakan lembaga yang menjadi penggerak perekonomian dan menjadi bagian dari pembiayaan perusahaan-perusahaan di berbagai sektor. Perbankan harus mengetahui seberapa besar kualitas perusahaannya dan posisi peringkat obligasinya agar dapat menarik investor dan peran tersebut dapat terlaksana. Dalam penilaian rasio keuangan lembaga keuangan perbankan yang digunakan adalah rasio likuiditas, solvabilitas dan rentabilitas.

Rasio likuiditas digunakan untuk mengukur kemampuan bank dalam memenuhi kewajiban jangka pendeknya. Apabila semakin besar rasio likuiditas bank maka dapat dikatakan semakin likuid bank tersebut, maka akan dapat mempengaruhi emisi obligasi yang dikeluarkan dan akan berdampak pada peringkat oblogasi yang diperoleh. Rasio solvabilitas atau bisa disebut rasio permodalan adalah rasio yang digunakan mengukur kemampuan bank mencari sumber dana untuk membiayai kegiatan bank serta melihat efisiensi pihak manajemen bank dengan modal yang mencukupi, memungkinkan manajemen bank yang bersangkutan untuk bekerja dengan efisiensi yang tinggi seperti yang dikehendaki oleh para pemilik modal pada bank tersebut. Permodalan yang besar akan dapat menaikkan peringkat obligasi yang diterima oleh suatu lembaga keuangan perbankan. Rasio rentabilitas adalah rasio yang digunakan untuk mengukur tingkat efisiensi usaha dan profitabilitas yang dicapai oleh bank atau rasio untuk mengukur kemampuan perusahaan dalam memperoleh laba atau keuntungan. Rasio rentabilitas bertujuan untuk mengetahui kemampuan bank dalam menghasilkan laba selama periode tertentu. Apabila laba yang dihasilkan semakin besar, maka dapat mempengaruhi jumlah emisi obligasi yang akan meningkatkan peringkat obligasi yang diperoleh lembaga keuangan perbankan. Berdasarkan latar belakang tersebut, dapat dilihat bahwa praktik manajemen laba itu sangat mungkin dilakukan oleh manajer sebagai pengelola.

\section{KAJIAN PUSTAKA}

1. Manajemen laba

Manajemen laba melalui kebijakan akuntansi merujuk pada permainan angka laba yang dilakukan menggunakan teknik dan kebijakan akuntansi. Sementara manajemen laba melalui aktivitas riil merujuk pada permainan angka laba yang dilakukan melalui aktivitas-aktivitas yang berasal dari kegiatan bisnis atau yang berhubungan dengan kegiatan operasional (Sulistiawan, 2011). Perhitungan penerapan manjemen laba menggunakan rumus total akrual dari Healy yang tercantum dalam Sari dan Bandi (2010) yaitu :

$\mathrm{EDA}_{\mathrm{it}}=\frac{\mathrm{TA}_{\mathrm{it}}}{\mathrm{A}_{\mathrm{it}-1}}$

\section{Kinerja Keuangan}

Kinerja keuangan merupakan gambaran dari pencapaian keberhasilan perusahaan dapat diartikan sebagai hasil yang telah dicapai atas berbagai aktivitas yang telah dilakukan. Dapat dijelaskan bahwa kinerja keuangan adalah suatu analisis yang dilakukan untuk melihat sejauh mana suatu perusahaan telah melaksanakan dengan menggunakan aturan-aturan pelaksanaan keuangan secara 
baik dan benar (Munawir, 2012). Dalam penilaian kinerja keuangan dapat dilakukan dengan analisis rasio keuangan.

\section{Rasio Likuiditas}

Rasio likuiditas adalah kemampuan perusahaan untuk memenuhi kewajiban jangka pendeknya tepat waktu. Rasio likuiditas yang digunakan dalam penelitian ini adalah quick ratio, yang digunakan untuk mengukur kemampuan bank dalam memenuhi kewajibannya terhadap para deposan (pemilik simpanan giro, tabungan dan deposito) dengan harta yang paling likuid yang dimiliki oleh suatu bank. Rumus untuk mencari quick ratio adalah dengan membagi cash assets dengan total deposit. (Kasmir, 2010)

\section{Rasio Solvabilitas}

$$
\text { Quick Ratio }=\frac{\text { Cash Assets }}{\text { Total Deposit }} \times 100 \%
$$

rasio solvabilitas atau bisa disebut permodalan adalah rasio yang digunakan mengukur kemampuan bank mencari sumber dana untuk membiayai kegiatan bank. Rasio solvabilitas yang digunakan adalah primary ratio, yang merupakan rasio yang digunakan untuk mengetahui apakah permodalan yang dimiliki sudah memadai atau sejauh mana penurunan yang terjadi dalam total aset dapat ditutupi oleh modal sendiri. Rumus untuk mencari primary ratio adalah dengan membagi equity capital dengan total aset. (Kasmir, 2010)

\section{Rasio Rentabilitas}

$$
P R=\frac{\text { Equity Capital }}{\text { Total Assets }} \times 100 \%
$$

Rasio profitabilitas adalah kemampuan dari suatu perusahaan untuk menghasilkan laba atau keuntungan dari modal perusahaan tersebut. Rasio rentabilitas yang digunakan dalam penelitian ini adalah return on equity, yang merupakan rasio yang digunakan untuk mengukur kemampuan manajemen bank dalam mengelola modal yang ada untuk mendapatkan net income. (Kasmir, 2010)

\section{Peringkat Obligasi}

$$
R O E=\frac{\text { Net Income }}{\text { Equity Capital }} \times 100 \%
$$

Surat utang obligasi adalah surat utang jangka menengah panjang yang dapat dipindah tangankan, berisi janji dari pihak yang menerbitkan untuk membayar imbalan berupa bunga pada periode tertentu dan melunasi pokok utang pada waktu yang telah ditentukan pada pihak pembeli.

Proses pemberian peringkat obligasi adalah dengan cara menunjuk satu lembaga pemeringkat. Setelah ada kesepakatan antara emiten dan lembaga rating, pihak manajemen menyerahkan data yang dibutuhkan untuk proses pemeringkatan. Kemudian survei dan wawancara akan dilakukan terhadap pihak manajemen.

Fungsi utama lembaga pemeringkat adalah memberikan rating yang obyektif, independen dan kredibel terhadap resiko kredit dari sekuritas yang diterbitkan secara umum melalui kegiatan rating. Di Indonesia lembaga yang memberikan peringkat obligasi adalah PT. PEFINDO.

\section{METODE PENELITIAN}

Penelitian ini menggunakan pendekatan kuantitatif dengan menggunakan data sekunder yaitu berupa laporan keuangan dan data peringkat obligasi lembaga 
Jurnal Cendekia Akuntansi Vol. 1 No. 1

keuangan perbankan yang terdaftar di Bursa Efek Indonesia tahun 2015-2017. Sampel dalam penelitian ini dipilih dengan menggunakan metode purposive sampling. Perusahaan yang menjadi sampel dalam penelitian ini berjumlah 6 perusahaan. Analisis data yang digunakan adalah analisis regresi linier berganda

IV. HASIL DAN PEMBAHASAN

1. Uji Signifikan Parsial (Uji - t)

2.

Tabel 3

Hasil Uji Signifikan parsial $(\mathbf{U j i}-\mathrm{t})$

Coefficients $^{\mathrm{a}}$

\begin{tabular}{|c|c|c|c|c|c|c|}
\hline \multirow[b]{2}{*}{ Mode } & & \multicolumn{2}{|c|}{ Unstandardized Coefficients } & \multirow{2}{*}{$\begin{array}{c}\begin{array}{c}\text { Standardized } \\
\text { Coefficients }\end{array} \\
\text { Beta }\end{array}$} & \multirow[b]{2}{*}{$\mathrm{t}$} & \multirow[b]{2}{*}{ Sig. } \\
\hline & & B & Std. Error & & & \\
\hline \multirow[t]{5}{*}{1} & $\begin{array}{l}\text { (Constan } \\
\text { t) }\end{array}$ & 12.356 & 2.481 & & 4.981 & .000 \\
\hline & MJL & 1.067 & .504 & .309 & 2.115 & .054 \\
\hline & QR & -.445 & .198 & -.330 & -2.254 & .042 \\
\hline & PR & .791 & .150 & .744 & 5.292 & .000 \\
\hline & ROE & -.062 & .045 & -.195 & -1.383 & .190 \\
\hline
\end{tabular}

a. Dependent Variable: PO

1. Manajemen Laba

Berdasarkan tabel persamaan regresi diperoleh nilai signifikansi 0,054 nilai signifikan $t>0,05$ maka maka ho diterima dan ha ditolak, maka dapat dikatakan bahwa manajemen laba tidak berpengaruh terhadap peringkat obligasi.

2. Quick Ratio

Berdasarkan tabel persamaan regresi diperoleh nilai signifikansi 0,042 nilai signifikan $\mathrm{t}<0,05$ maka ho ditolak dan ha diterima, maka dapat dikatakan bahwa quick ratio berpengaruh terhadap peringkat obligasi.

\section{Primary Ratio}

Berdasarkan tabel persamaan regresi diperoleh nilai signifikansi 0,000 nilai signifikan $\mathrm{t}>0,05$ maka maka ho ditolak dan ha diterima, maka dapat dikatakan bahwa primary ratio berpengaruh terhadap peringkat obligasi.

4.Return On Equity

Berdasarkan tabel persamaan regresi diperoleh nilai signifikansi 0,190 nilai signifikan >0,05, maka maka ho diterima dan ha ditolak, maka dapat dikatakan bahwa return on equity tidak berpengaruh terhadap peringkat obligasi.

\section{Uji Signifikan Simultan (Uji - F)}

\section{Tabel 4}

Hasil Uji Signifikan Simultan (Uji - F)

ANOVA $^{b}$

\begin{tabular}{|ll|r|r|r|r|r|}
\hline Model & Sum of Squares & df & Mean Square & F & Sig. \\
\hline 1 & Regression & 118.067 & 4 & 29.517 & 9.490 & $.001^{a}$ \\
& Residual & 40.433 & 13 & 3.110 & & \\
& Total & 158.500 & 17 & & & \\
\hline
\end{tabular}


Berdasarkan tabel persamaan regresi diperoleh nilai signifikansi 0,001 nilai signifikan $<0,05$, maka ho ditolak dan ha diterima, maka dapat dikatakan bahwa variabel independen berpengaruh secara simultan terhadap variabel dependen.

\section{Pembahasan}

\section{a. Pengaruh manajemen laba terhadap peringkat obligasi}

Berdasarkan tabel persamaan regresi diperoleh nilai signifikansi 0,054 nilai signifikan $\mathrm{t}>0,05$ maka maka ho diterima dan ha ditolak, maka dapat dikatakan bahwa manajemen laba tidak berpengaruh terhadap peringkat obligasi. Dari hasil pengujian yang telah dilakukan hasilnya menyatakan bahwa manajemen laba tidak berpengaruh terhadap peringkat obligasi pada lembaga keuangan perbankan yang terdaftar di Bursa Efek Indonesia. Hasil penelitian berbeda dengan penelitian penelitian terdahulu yang dilakukan oleh Sari dan Bandi (2010) dikarenakan sampel yang digunakan berbeda. Penelitian Sari dan Bandi menggunakan perusahaan manufaktur penelitian sekarang menggunakan lembaga keuangan perbankan.

Dalam kegiatan operasinya, perusahaan manufaktur berbeda dengan lembaga keuangan perbankan. Perusahaan manufaktur memproduksi bahan baku mentah menjadi produk setengah jadi ataupun menjadi produk jadi, sehingga asset yang dimiliki banyak. Sedangkan lembaga keuangan perbankan hanya menghasilkan jasa dan aset yang dimiliki lebih sedikit daripada perusahaan manufaktur. Sehingga rasio tersebut tidak dapat digunakan untuk memprediksi peringkat obligasi dimasa mendatang.

\section{b. Pengaruh rasio likuiditas yang diproksikan dengan quick ratio terhadap peringkat obligasi}

Berdasarkan tabel persamaan regresi diperoleh nilai signifikansi 0,042 nilai signifikan $\mathrm{t}<0,05$ maka ho ditolak dan ha diterima, maka dapat dikatakan bahwa quick ratio berpengaruh terhadap peringkat obligasi. Dari hasil pengujian yang telah dilakukan hasilnya menyatakan bahwa quick ratio berpengaruh terhadap peringkat obligasi pada lembaga keuangan perbankan yang terdaftar di Bursa Efek Indonesia. Hasil penelitian Hasil penelitian sama dengan penelitian penelitian terdahulu yang dilakukan oleh Widiyantoro (2013), yakni likuiditas mempengaruhi peringkat obligasi yang diperoleh. Hal ini sesuai dengan teori dari Kasmir (2010) yang menyatakan bahwa semakin besar rasio likuiditas bank maka dapat dikatakan semakin likuid bank tersebut, karena cash assets yang dimiliki lebih besar dari total deposit. Sehingga apabila suatu waktu terjadi perubahan kondisi ekonomi atau keuangan maka aktiva cepat tersebut dapat digunakan untuk memenuhi kewajiban perusahaan yang terkait dengan obligasi. Jadi para pemegang obligasi (investor) akan merasa aman untuk investasi pada perusahaan karena likuiditas yang tinggi akan mengurangi resiko kegagalan obligasi, sehingga akan menaikkan peringkat obligasi yang diperoleh. Sehingga rasio tersebut dapat digunakan untuk memprediksi peringkat obligasi dimasa mendatang.

\section{c. Pengaruh rasio solvabilitas yang diproksikan dengan primary ratio terhadap peringkat obligasi}

Berdasarkan tabel persamaan regresi diperoleh nilai signifikansi 0,000 nilai signifikan $\mathrm{t}>0,05$ maka maka ho ditolak dan ha diterima, maka dapat dikatakan bahwa primary ratio berpengaruh terhadap peringkat obligasi. Dari 
hasil pengujian yang telah dilakukan hasilnya menyatakan bahwa primary ratio berpengaruh terhadap peringkat obligasi pada lembaga keuangan perbankan yang terdaftar di Bursa Efek Indonesia. Hasil penelitian sesuai dengan penelitian Rusfika dan Wahidawati tahun (2015), yang menunjukkan bahwa rasio solvabilitas pengaruh terhadap peringkat obligasi perusahaan. Hal ini sesuai dengan pernyataan dari Kasmir (2010) yang menyebutkan bahwa dengan modal yang mencukupi, berati kemampuan bank mencari sumber dana untuk membiayai kegiatan bank dapat dikatakan baik. Berarti total modal lebih besar daripada total asset.

Permodalan yang tinggi memungkinkan manajemen bank yang bersangkutan untuk bekerja dengan efisiensi seperti yang dikehendaki oleh para pemilik modal pada bank tersebut. Permodalan yang besar akan dapat menaikkan peringkat obligasi yang diterima oleh suatu lembaga keuangan perbankan. Sehingga rasio tersebut dapat digunakan untuk memprediksi peringkat obligasi dimasa mendatang.

d. Pengaruh rasio rentabilitas yang diproksikan dengan return on equity terhadap peringkat obligasi

Berdasarkan tabel persamaan regresi diperoleh nilai signifikansi 0,190 nilai signifikan $>0,05$, maka maka ho diterima dan ha ditolak, maka dapat dikatakan bahwa return on equity tidak berpengaruh terhadap peringkat obligasi.

Dari hasil pengujian yang telah dilakukan hasilnya menyatakan bahwa return on equity tidak berpengaruh terhadap peringkat obligasi pada lembaga keuangan perbankan yang terdaftar di Bursa Efek Indonesia. Hasil penelitian sama dengan penelitian penelitian terdahulu yang dilakukan oleh Widiyantoro (2013), yang menunjukkan bahwa rasio rentabilitas tidak berpengaruh terhadap peringkat obligasi. Hal ini dikarenakan kemampuan bank dalam menghasilkan laba bersih dengan menggunakan modal sendiri yang relatif rendah. Semakin rendah rasio rentabilitas, maka kemampuam perusahaan untuk membayar kewajiban menjadi kurang baik. Jadi semakin rendah rasio rentabilitas akan mengandung resiko yang tinggi dan menyebabkan peringkat obligasi yang kurang baik. Sehingga rasio tersebut tidak dapat digunakan untuk memprediksi peringkat obligasi dimasa mendatang.

e. Pengaruh manajemen laba, rasio likuiditas yang diproksikan dengan quick ratio, rasio solvabilitas yang diproksikan dengan primary ratio dan rasio rentabilitas yang diproksikan dengan return on equity secara simultan terhadap peringkat oblligasi

Berdasarkan tabel persamaan regresi diperoleh nilai signifikansi 0,001 nilai signifikan $<0,05$, maka ho ditolak dan ha diterima, maka dapat dikatakan bahwa variabel independen berpengaruh secara simultan terhadap variabel dependen.Dari hasil pengujian yang telah dilakukan hasilnya menyatakan bahwa dapat dikatakan bahwa variabel independen berpengaruh secara simultan terhadap variabel dependen. Hal ini dikarenakan secara bersama-sama variabel manajemen laba dan kinerja keuangan berpengaruh terhadap peringkat obligasi. Artinya, setiap perubahan yang terjadi pada manajemen laba dan kinerja keuangan bank, maka akan berpengaruh terhadap peringkat obligasi pada lembaga keuangan perbankan. 


\section{KESIMPULAN DAN SARAN}

\section{Kesimpulan}

Penelitian yang dilakukan bertujuan untuk menguji pengaruh manajemen laba dan kinerja keuangan terhadap peringkat obligasi (studi kasus pada lembaga keuangan perbankan di bursa efek indonesia). Pengukuran manajemen laba menggunakan rumus total akrual dari Healy yang tercantum dalam Sari dan Bandi (2010). Pengukuran kinerja keuangan menggunakan quick ratio, primary ratio dan return on equity. Hasil pengujian hipotesis dengan menggunakan analisis statistik deskriptif dan analisis regresi linier berganda. Dengan empat variabel independen ( manajemen laba, quick ratio, primary ratio dan return on equity ) dan satu variabel dependen yakni peringkat obligasi menunjukkan bahwa: variabel manajemen laba tidak berpengaruh terhadap peringkat obligasi, variabel rasio likuiditas yang diproksikan dengan quick ratio berpengaruh terhadap peringkat obligasi, variabel rasio solvabilitas yang diproksikan dengan primary ratio berpengaruh terhadap peringkat obligasi, variabel rasio rentabilitas yang diproksikan dengan return on equity tidak berpengaruh terhadap peringkat obligasi, variabel manajemen laba dan kinerja keuangan bank antara lain quick ratio, primary ratio dan return on equity secara simultan mempengaruhi peringkat obligasi pada lembaga keuangan perbankan selama periode 2015 - 2017 dengan nilai signifikansi 0,001 .

\section{Saran}

Berdasarkan kesimpulan diatas, maka penulis mengajukan beberapa saran sebagai berikut:

a. Bagi para investor dan calon investor, dalam mengambil keputusan investasi disarankan untuk memperhatikan informasi akuntansi yang berupa laba yang diperoleh dan rasio-rasio keuangan agar keputusan yang diambil dapat memberikan hasil yang terbaik dan terhindar dari kerugian yang berakibat fatal.

b. Bagi Lembaga Keuangan Perbankan :

Perlu meningkatkan pemahaman mengenai manajemen laba, dimana hal tersebut dapat membantu organisasi untuk menghindari risiko yang timbul dari penerapan manajemen laba. Penerapan yang tidak tepat dapat menyebabkan masalah yang besar terhadap pelaporan keuangan.

c. Bagi peneliti selanjutnya, diharapkan dapat menambah sampel penelitian, dan menggunakan periode yang lebih panjang dari 3 tahun, sehingga mendapatkan hasil yang lebih kuat, dan melakukan penelitian dengan menggunakan sampel lembaga keuangan selain perbankan, misalnya finance, asuransi dan lain-lain.

\section{DAFTAR PUSTAKA}

Amalia, Ninik. 2013. "Pemeringkatan Obligasi PT. Pefindo: Berdasarkan Informasi Keuangan”. Accounting Analysis Journal. Vol. 2. No. 2. Pp 139147.

Harahap, Sofyan Syafri, (2006), Analisis Kritis atas Laporan Keuangan, Edisi Pertama, Jakarta : PT Raja Grafindo Persada

https://www.idx.co.id/ 
Jurnal Cendekia Akuntansi Vol. 1 No. 1

http://www.pefindo.com/

Kasmir, S.E., MM. 2010.Manajemen Perbankan. Jakarta: Rajawali Press.

Kasmir, S.E., MM. 2012.Analisis Laporan Keuangan. Jakarta: Rajawali Press.

Munawir, S. 2012. Analisis Informasi Keuangan, Liberty, Yogyakarta.

Padmantyo, Sri 2010. "Analisis manajemen labapada laporan keuangan perbankan syariah".Sukoharjo :Jurnal Manajemen dan BisnisVolume 14, Nomor 2, Desember 2010, hlm. 53-65.

Raharja, Sari. 2008. "Kemampuan Rasio Keuangan dalam Memprediksi Peringkat Obligasi (PT Kasnic Credit Rating)". Jurnal Maksi, Vol. 8.

Rusfika, Wahidahwati. 2015. "Kemampuan Faktor Akuntansi dan Non Akuntansi dalam Memprediksi Bond Rating”.Jurnal Ilmu \& Riset Akuntansi. Vol 4. No 4. Pp 1-17.

Sari, Syarifah dan Bandi . 2010. "Praktik Managemen Laba Terkait Peringkat Obligasi". Simposium Nasional Akuntansi XIII Purwokerto.

Sulistiawan, Dedhy., Yeni Januarsi, Liza Alvia. 2011. Creative Accounting. Jakarta : Penerbit Salemba Empat.

Sutrisno. (2009), Manajemen Keuangan teori, Konsep dan aplikasi. Edisi Pertama, Cetakan ketujuh, Yogyakarta : Ekonisia Kampus Fakultas Ekonomi

Widiyantoro, Nur. 2013. Analisis faktor-faktor yang mempengaruhi prediksi peringkat obligasi. Surakarta : Atikel Ilmiah.

Yani, Ahmad, Marhaendra, Kusuma. 2017. Buku Panduan Praktikum Laboratorium Akuntansi SPSS. Kediri : Universitas Islam Kadiri.

Yasa, Gerianta Wirawan. 2010. Pemeringkatan Obligasi Perdana Sebagai Pemicu Manajemen Laba. Purwokerto : Simposium Nasional Akuntansi XIII. 